'Once upon a time, Santos was reading about the Sahuayo zombies when': performances of (post)modernity and nationalism by Mexican zombies

Ramirez Ladron de Guevara, V

http://hdl.handle.net/10026.1/8217

10.1080/01439685.2014.974361

Studies in Theatre and Performance

Informa UK Limited

All content in PEARL is protected by copyright law. Author manuscripts are made available in accordance with publisher policies. Please cite only the published version using the details provided on the item record or document. In the absence of an open licence (e.g. Creative Commons), permissions for further reuse of content should be sought from the publisher or author. 


\section{"Once upon a time, Santos was reading about the Sahuayo zombies when...": Performances of (post)modernity and nationalism by Mexican zombies}

Victor Ramirez Ladron de Guevara

School of Humanities \& Performing Arts, Plymouth University

In a country where there has been a continuous and enormous effort to create a homogenous and stable national identity, ${ }^{1}$ the figure of the zombie points variously (and simultaneously) to past, present and (imagined) future Mexican national identities that are suppressed and/or encouraged. The hegemonic conception of Mexican identity largely centres on the mestizo, a term that refers both to the offspring of native indigenous Mexicans and Spanish colonisers, as well as the hybrid culture created as a result of that (rather violent) “encounter". However, as Stephen D. Morris has noted the "Mexican national identity contains a wide mix of expressions and components" (1999, 370) amongst which can be highlighted the pride and reverence for the indigenous preHispanic past and a number of western tenets embraced by the Mexican Revolution (such as democracy, liberalism and social justice). These seemingly paradoxical elements are reflected in the four cultural representations analysed in this article: the 1962 film, El Santo versus the zombies; the 1990 comic strip, El Santos contra la Tetona Mendoza; the 2010 movie trailer, Zombies del Bicentenario; and the 2011 Zombie Walk in Mexico City. At the moment of their creation, each indicated a paradigmatic shift in the construction of the Mexican national identity.

\section{Santo vs. the Zombies}

Lucha libre is a form of professional wrestling in Mexico characterised by its vibrant and colourful masks and which spectacularly emphasises the use of locks and impressive aerial stunts. The most famous and emblematic wrestler in the history of the 
sport is El Santo, El Enmascarado de Plata (The Saint, The Silver Masked Man). ${ }^{2} \mathrm{He}$ was a luchador (or wrestling character) created and performed by Rodolfo Guzmán Huerta who, in an astonishing display of commitment, played this role for over forty years. During this time, he rarely appeared in public without wearing his legendary mask and he guarded his secret identity fiercely (Levi 2008, 111-2). The only time he removed his mask in public was in a TV interview in 1984, one week before his death. After his demise, following his wishes, he was buried with his mask on. While the name of the man beneath the mask is largely unknown by fans and the general public, the name El Santo is immediately recognised by Mexicans of all ages and social classes. His iconic figure still serves as the template of all successive wrestlers and it is firmly inscribed in the collective imagery of most Mexicans. ${ }^{3}$

Guzmán's fame and legacy however, were not cemented through his exploits in the wrestling ring, but in a series of 52 movies that were produced between 1958 and 1982. In his first two films he only appeared as an incidental character and a sidekick to another wrestler. However, in his third film, Santo vs. the Zombies (Santo contra los Zombis), he is the central character, playing "himself" (a professional wrestler) who is tasked with the duty of fighting evil. This takes the form of an evildoer/mad scientist who uses a concoction of technology and stolen knowledge (he kidnaps a professor who is a specialist in Haitian rituals) to raise a zombie army. These zombie minions are sent to commit a series of jewellery thefts, which they can do rather effectively as they are able, amongst their other traits, to withstand bullets. Santo is asked to investigate the disappearance of the missing professor and to fight the zombies, which he does both inside and outside the wrestling ring.

As with all Santo movies, the production values mirror those of Hollywood Bgrade movies. There are several significant plot holes, the acting style is exaggerated 
and unconvincing, and the special effects are basic. The emergence of the wrestling movies genre in Mexico belong to a historical era in which, as Schmelz points out, "the dream of the so-called golden age collapsed" (in Paz 2008, 84). Due to a combination of lack of funding, the establishment of film industry monopolies and union disputes toward the end of 1950s, "quality" Mexican cinema became a rarity and began to be replaced with products of "inferior" value. At the same time, Mexico was experiencing an ideological, political and economical shift as its "predominantly agricultural economy was transformed into a manufacturing one, and [its] agrarian society began to make the qualitative leap into a typically urban one" (Vitali 2010, 143-4).

In Santo vs. the Zombies, El Santo is the epitome of the movement towards such modernity. He is presented as a Batman-like figure with a number of gadgets, a secret lair and a sports car at his disposal. The sense of modernity is reinforced by the costumes worn by the characters, the presence of a female investigator and the portrayal of newly built avenues across Mexico City. The only thing that disrupts the urban sphere is the emergence of magical creatures that point to ancient and traditional knowledge. In this sense, it is possible to argue that the zombies that Santo fights in this movie function as indigenous signifiers: pre-Hispanic phenomena that no longer fit the modern way of living that he represents.

The zombies of this film are the result of an appropriation of voodoo techniques and thus anchored in an indigenous belief system. Although voodoo is not a Mexican indigenous tradition, its foreign nature may have allowed the filmmakers to take a more critical and negative stand against indigenous beliefs in general and portray them as diametrically opposed to El Santo's “enlightened” approach. El Santo’s fight against these enchanted creatures is not only an act of heroism but also a clear endeavour to facilitate the construction of a Mexican national identity that rejects its indigenous roots. 
Paradoxically, in Mexico the indigenous is often used to glorify the nation's past and to claim a sense of tradition and legacy, yet there is also "a discourse that casts the Indian and the Indian culture as not truly Mexican, but rather as impediments to the unification of the nation and obstacles to its political, economic and cultural development: in short, a threat to the nation's interests" (Morris 1999, 374).

The zombies in Santo vs. the Zombies are empty vessels, manipulated thanks to the use of technology; they are able to drive, to fight, to wrestle in official matches in front of adoring crowds, to execute kidnapping ploys and to teleport themselves when they need to escape. As El Santo finds out towards the end of the film, without their "special" belts they become inanimate objects, nothing more than dolls without will or desire. In other words, the indigenous content signalled by the use of voodoo is assimilated within a new order provided by a mestizo identity, "transforming the indigenous both racially and culturally, thereby forging national unity and overcoming obstacles to development” (Morris 1999, 374).

As the film career of El Santo continued, his mestizo quality was emphasized as he became more "modern". He began to wear suits and ties and his gadget collection improved (he eventually possessed a time machine, for example). Yet, the "protoindigenous" content present in his first fight against zombies would reappear as the plots of his movies became more chaotic and fantastic. He fought against women werewolves, Guanajuato-mummies, and journeyed to the land of the dead whilst undergoing openheart surgery in a film which uses actual footage of an open heart operation. Santo, and by extension Mexico's modernity, is enacted through the continuous suppression of a zombie (that is, of indigenous attributes). This is ultimately self-defeating, as indigenous traits of identity always resurface and problematize the "modern" stance of the mestizo identity. 4 


\section{The Zombies of Sahuayo: The Mexican Average Joe}

Almost thirty years after Santo vs. the Zombies, a comic strip drawn by Jis and Trino started appearing in the weekly cultural supplement of the leading national left-wing newspaper, La Jornada. ${ }^{5}$ In El Santos contra la Tetona Mendoza (Santos vs. the Busty Mendoza), the main character's name is a clear allusion to the wrestler El Santo, reifying the mythical aspect of this figure but also debasing it. In the comic, El Santos is a "hero" who is constantly called to solve the city's problems . Each instalment of this comic strip begins with the legend, "Once upon a time Santos was...", and the stories deal mostly with sex, drugs, obscenity, profanity, and all sorts of behaviours that could cause moral outrage in the conservative sections of the Mexican population. "Busty" Mendoza is his sometime-wife, a voluptuous female wrestler and brothel-owner, and its other staple characters include the Peyote Killer, Godzilla, and the Sahuayo zombies. ${ }^{6}$ El Santos variously fights, takes drugs and has sex with these characters whilst together they engage in a number of rude, subversive and hallucinatory adventures.

El Santos contra la Tetona Mendoza was clearly situated within a political context which it questions through subversion. In1988, Carlos Salinas de Gortari won the presidency of Mexico as a result of what is now largely agreed to have been electoral fraud of massive proportions. This was the first time in sixty years that the PRI (Mexico's ruling party at the time) ${ }^{7}$ was on the verge of losing an election. The PRI presented itself as the ideological embodiment of the Mexican Revolution, fought between 1910 and 1917, and asserted its right to govern Mexico as the only way to safeguard its national interests. Its fraudulent triumph in 1988 served to reinforce a perception of invulnerability as all fraud complaints were received by judiciary courts which were controlled by the same party and thus it helped to strengthen its narrative of national identity. 
Jis and Trino's comic seeks to transgress all limits of what was considered to be normal at the time (several strips make explicit their attempt to avoid censorship for example) and to disrupt conventions of what was deemed acceptable. Although not overtly or explicitly political, its weekly publication in one of the most important leftwing newspapers can be interpreted as an attempt to break the perceived link between the ruling national party's ideology and the dominant national identity. Yet, El Santos contra la Tetona Mendoza does not propose any alternative. It is satisfied with both subverting and reaffirming values, ideas and practices. As such, the comic strip situates itself within a postmodern approach to the issue of national identity. This approach is mirrored in its use of stylistic resources such as repetition and collage, the mix of upper and lower cultural registers, and the introduction of metatextual devices. ${ }^{8}$

Interestingly, the only characters who rarely perform any transgressive acts are the Sahuayo zombies and this is because they are quite normal. They are rather passive and do not often engage in fights with other characters. They do not seek to infect anyone and only reproduce when other characters chop off their limbs. The Sahuayo zombies have an artistic taste that has been modelled by the mass media and are blind followers of the ruling ideology. In one of the comic strips, for example, one of the zombies is ridiculed for displaying a poster of a Z-list TV celebrity in his bedroom. They are, in fact, the Mexican equivalent of the American "average Joe". They function as "traditional", stable referents to both the indigenous and the mestizo/modern registers of Mexican identity: registers that no longer seem to operate effectively at this particular historic moment. As such, Sahuayo zombies are expendable which is indicated by the way they are continuously used as cannon fodder: mutilated, ridiculed and even urinated upon throughout instalments of the comic strip. Here, the zombie works as an "other" opposed to the newly embraced postmodern condition. 
Roger Bartra coined the term "postMexican condition" to describe the profound disruption of traditional Mexican understandings of identity by such postmodern perspectives $(2005,306)$. Framed by the inception of the North American Free Trade Agreement (NAFTA) between Mexico, the USA, and Canada in 1994 and the collapse of communist regimes (which until then, had provided ideological sustenance to the parties on Mexico's political left), this perceived identity “crisis" is performed in the El Santos strips in a playful and irreverent way: always on the verge of fracture, rejoicing in its gaps and contradictions, with full awareness that the system is broken. And not caring too much about it.

\section{Bicentenary Year Zombies}

In 2010, a trailer for a film entitled Zombies del Bicentenario (Bicentenary Year Zombies) was released on Youtube, creating expectation and causing consternation in equal measure. This year was the two-hundredth anniversary of the beginning of the war of independence between Mexico and Spain. The trailer suggested that in the film, the leaders of the Mexican Independence movement would return as zombies and infect the general population.

The war of independence is one of the main originators of a shared sense of Mexican national identity. As such, the return of its heroes as zombies denoted overt accusation of the betrayal of its core ideas and principles. In other words, the trailer could be interpreted as a critique of globalisation and USAmerican political and cultural dominance. One of the ways in which Mexican national identity has been constructed is as a reaction against the USA. Morris notes the way in which "the humiliation, deprivation and oppression suffered historically at the hands of the USA provides a common foundation that strengthens the sense of national identity and imbues it with a 
shared sense of distrust toward the USA" $(1999,371)$.

Moreover, in the years between the publication of El Santos' comic strip and the release of this trailer, there was a significant and concerted effort to highlight mestizo (upper class) iconographies and national identity foundational myths (Barrios 2001). Yet, there are numerous elements in the trailer that extend beyond traditional mestizo approaches and strategies. There is, for example, the appropriation of a sci-fi format (the "disaster film") commonly found in Hollywood blockbusters but "completely absent from Latin America cinema" (Paz 2008, 99), suggesting that the zombie here has acquired a quasi-postcolonial dimension. Edna Azenberg, in her analysis of Niyi Ozundare's The Famished Road, describes the use of the zombie-like figure of the abiku which enables her to position Ozundare's work within a postcolonial field. Azenberg's description can be applied equally to Zombies del Bicentenario, with its "cacophony of reality immediately and solidly engaged in its multiple dimensions, living and dead, spiritual and material, old and new, good and bad, peaceful and violent, a reality assumed without anguishing either/ors or in-betweens" $(1999,465)$.

And yet, there is also a clearly nationalist political dimension embedded in this trailer as well. Its voiceover features an edited version of two actual speeches by Felipe Calderon Hinojosa, who was then president of Mexico. In the first, he invites Mexicans to celebrate the Mexican Independence Bicentennial Anniversary. In the second, he outlines the government strategies that will be put in place as a result of the swine flu crisis in 2009. The abridged version of Calderon's speeches in the trailer for Zombies del Bicentenario includes the following words:

During the last days, the whole country has focused its energy facing a virus.... A great number of people have been infected and many more have died.... The battlefront is Mexico and in this trench we are defending not only Mexicans, but also all human beings in the world 
that can get infected with this new disease. ${ }^{9}$

Thus, swine flu works as a metaphor for the zombie virus. Having been placed at the centre of a global pandemic, Calderon reflects two new positions currently affecting Mexican national identity: one, the Mexican as a globalised being who is no longer only a passive receiver but who has now become an agent of change; two, the possibility and responsibility of Mexico acting as the safeguard of a global community.

\section{The Cultural Memories of Walking Zombies}

Shortly after appearing online, it was revealed that the trailer was bogus, and that there was no full length movie version of Zombies del Bicentenario. Instead, the trailer was partly created to encourage people to participate in a Zombie Walk in Mexico City: an event in which many of the key elements of Mexican national identity previously identified (in the Santo film, the comic strip and the trailer above) are present.

The 2011 Zombie Walk in Mexico City shared many common characteristics with other Zombie Walks across the world. It was held on a random date, intervened in an urban space, and featured a large number of people in heavy make up slowly walking and demanding to ingest brains (do Vale 2010, 192). Yet, there is one element that distinguishes this event from similar ones at the time. Although, as do Vale argues, Zombie Walks across the world provide "an ironic kind of resistance against mainstream culture and values" in Mexico (2010, 193), the sense of resistance was completely overpowered by a sense of celebration, most evident in choices of costume.

In this walk, participants not only dressed as zombies, they also performed zombified versions of iconic Hollywood characters (zombified versions of Charlie Chaplin, Wolverine, and Marilyn Monroe were highly visible during the march). Other Zombie Walks across the world privilege the recreation of a specific number of zombie 
types such as "nurse zombie, business person zombie, geek zombie, sports zombie" (Lauro 2011, 214). However, in Mexico's Zombie Walk the participants reinforced their condition as globalised citizens by performing a dual role, both of a zombie and of a Hollywood iconic figure. The appropriation/cannibalisation of those figures may point towards a postcolonial approach, but it may also indicate an attempt to position the Mexican as a globalised subject, whose actions have an effect elsewhere in the world. ${ }^{10}$

As Diana Taylor has made clear, marches, demonstrations, and other public events can be understood as embodied events that can reveal a great deal of information about the culture in which those performances are situated (2003, 16-33). The 2011 Zombie Walk in Mexico City can be read as an attempt to reassert the mestizo's ownership of the city's streets, reinforcing a supposed hierarchical superiority over their indigenous counterpart. Mexico City's streets belong to the modern mestizos and there have been very few occasions when indigenous people have been able to occupy its streets. Amongst those few examples, probably one of the most poignant ones was the 2001 march by the EZNL into the main square of Mexico City. Anna Martinez (2013) describes and analyses the temporary inversion of power achieved by the indigenous Zapatistas during that massive popular demonstration.

In relation to this earlier demonstration, it is difficult to resist the association of zombies with indigenous Mexicans as previously suggested in this article. The sight of massed zombies reactivates the memory of thousands of marching Zapatistas in a nation that has continuously and successfully suppressed its indigenous roots. However, in Mexico City's 2011 Zombie Walk (unlike the temporary inversion of the 2001 EZNL march), the metaphorical indigenous zombie is once again trumped and relegated by the mestizo's appropriation of its globalised figure. As a reaffirmation of mestizo/modern values, it is highly significant that the meeting point for the beginning of this Zombie 
Walk was the Monument to the Revolution, and that it finished at the centre of the city, the Zocalo, “Mexico’s most contested public space” (Martinez 2013, 190).

Equally evident in this event, however, were the transgressive, playful and irreverent attitudes highlighted in the analysis of El Santo contra la Tetona Mendoza. In fact, in the march there were El Santo zombies, indigenous zombies, Hollywood zombies, and even Sahuayo zombies. There were also many other Mexicans in plain clothes who marched alongside their fellow zombified countrymen, performing each other's other. Together they were enacting national identities that always fall short, unable to fully express the complexities of contemporary Mexico.

It was precisely this heterogeneous mass of people that imbued this Zombie Walk with political qualities by alluding to disturbing home truths. In 2007, trying to eliminate a widespread perception of his government's illegitimacy, the president Felipe Calderon declared "war" on all drug cartels operating in the country. Since then, violence and criminality have increased tenfold and, as a result, more than 55,000 people have died and approximately 30,000 have disappeared. Once again, the zombie offers a poignant metaphor for Mexican national identity: 30,000 people are missing, trapped between the living and the dead, and between the past and a future that has not yet been formed. In the meantime, those who are left behind enact a very different kind of zombie: numb, but full of hope; weakened, but ready to fight. A zombie who waits for the return of loved ones.

\section{References}

Azenberg, Edna. 1999. “'I Walked with a Zombie': The Pleasures and Perils of Postcolonial Hybridity," World Literature Today, 73 (3): 461-466.

Barrios, Jose Luis. 2001. "Iconography Past and Present: Visual Constructions of Power in Post-PRI Mexico", Discourse, 23 (2): 26-43. 
Bartra, Roger. 1996. "Mexican Oficio: The Miseries and Splendors of Culture" in Claudia Ferman (ed), The Postmodern in Latin and Latino American Cultural

Narratives: Collected Essays and Interviews. New York: Garland Publishing, 29-40.

Bartra, Roger. 2005. "La Condición Postmexicana” in Roger Bartra (ed), Anatomía del Mexicano. Mexico D.F.: Debolsillo, 303-310.

Hegarty, Kerry T. 2013. "From Superhero to National Hero: The Populist Myth of El Santo", Studies in Latin American Popular Culture, 33: 3-27.

Holdsworth, Nadine. 2010. Theatre \& Nation. London: Palgrave McMillan.

Lauro, Sarah J. 2011. "Playing Dead: Zombies Invade Performance Art... and Your Neighborhood" in Deborah Christie and Sarah J. Lauro (eds), Better off Dead: The Evolution of the Zombie as Post-human. New York: Fordham University Press, 205-230

Levi, Heather. 2008. The World of Lucha Libre: Secrets, Revelations and Mexican National Identity. Durham: Duke University Press.

Martinez, Ana. 2013. "Distrito Federal: 'Global City, Ha, Ha, Ha!'” in D. J. Hopkins and Kim Solga (eds), Performance and the Global City. London: Palgrave Macmillan, 183-201.

Morris, Stephen D. 1999. "Reforming the Nation: Mexican Nationalism in Context", Journal of Latin American Studies, 31 (2): 363-397.

Paz, Mariano. 2008. "South of the future: an overview of Latin American Science Fiction Cinema”, Science Fiction Film and Television, 1 (1): 81-103.

do Vale, Simone. 2010. "Trash Mob: Zombie Walks and the Positivity of Monsters in Western Popular Culture" in Mikko Canini (ed), The Domination of Fear. Amsterdam: Rodopi, 191-202.

Vitali, Valentina. 2010. "Film Historography as Theory of the Film Subject: A Case Study”, Cinema Journal, 50 (1): 141-146.

Taylor, Diana. 2003. The Archive and the Repertoire: Performing Cultural Memory in the Americas. Durham and London: Duke University Press.

\section{Notes}

${ }^{1}$ In this respect, Mexico is no different from most other countries. For a summary of some of the main issues surrounding the concept of national identity, see Holdsworth (2010, 9-26).

${ }^{2}$ For an extended account of El Santo and the socio-historical context surrounding his filmic productions see Hegarty (2013).

${ }^{3}$ Interestingly, the iconic figure of the masked wrestler has also become representative of Mexico across the world.

${ }^{4}$ For a different interpretation of El Santo's representation of Mexican identity see Hegarty, who argues that El Santo's films denote a resistance to modernity through their emphasis on a traditional (predominantly mestizo) ideology (2013, 11-13).

${ }^{5}$ Jis is the name used by José Ignacio Solórzano and Trino is the pseudonym used by José Trinidad Camacho.

${ }^{6}$ Although usually translated into English as "Busty", the more literal translation of her name is "Big Titties" Mendoza. Sahuayo is a small town in the state of Michoacan in the southwest of Mexico. 
${ }^{7}$ PRI stands for Partido Revolucionario Institucional (Institutional Revolutionary Party).

${ }^{8}$ For a further exploration of the nexus between Mexican national identity, postmodernism and the production of cultural products see Bartra (1996, 35-37, 39, 40).

${ }^{9}$ Translation from Spanish by the author. The full version of this trailer is available at: http://www.youtube.com/watch?v=4cRpvdX3jS0.

${ }^{10}$ It is not a coincidence that one of the aims of the event was to break a Guinness World Record for numbers of marching zombies. 